\title{
THE ASSOCIATION OF SELECTED SPEEX-BATTERY INDICES WITH THE CONSTRUCTS OF THE MULTIFACTOR LEADERSHIP QUESTIONNAIRE
}

\author{
G SUGREEN \\ J M SCHEPERS \\ Department of Human Resources Management \\ University of Johannesburg
}

\begin{abstract}
The principal objective of the study was to determine the relationship between certain indices of the SPEEX-battery and the leadership dimensions of the MLQ. The SPEEX-battery was subjected to factor analysis and yielded six factors. The reliabilities of the composite scores calculated to represent each of the factors ranged from 0,712 to 0,925 . The MLQ was also subjected to factor analysis and yielded three factors. A canonical correlation of 0,666 $(\mathrm{p}<0,000001)$ was obtained between the indices of the SPEEX-battery (IV's) and the leadership dimensions of the MLQ (DV's). The implications of the findings are discussed.
\end{abstract}

\section{OPSOMMING}

Die hoofdoelwit van die studie was om die verband tussen sekere indekse van die SPEEX-battery en die leierskapsdimensies van die MLQ te bepaal. Die SPEEX-battery is aan 'n faktorontleding onderwerp en ses faktore is verkry. Saamgesteldetellings is bereken om elk van die faktore te verteenwoordig. Die verkreë betroubaarhede het gewissel van 0,712 tot 0,925 . Die MLQ is ook aan 'n faktorontleding onderwerp en drie faktore is verkry. 'n Kanoniese korrelasie van 0,666 ( $\mathrm{p}<0,000001$ ) is verkry tussen die dimensies van die SPEEX-battery (OV's) en die leierskapsdimensies van die MLQ (AV's). Die implikasies van die studie word bespreek.

Human beings differ considerably: each individual is unique by virtue of his/her personality traits and cognitive abilities, consequently, the ways in which individuals behave in particular situations, varies. And so do job performances. Therefore it is necessary to assess the knowledge, skills, abilities, personality and interests of applicants or candidates vying for particular positions as best and as accurately as possible. This is particularly true of candidates who aspire to leadership positions. Suitable measuring instruments for personnel selection must therefore be identified.

Establishing the predictive power of the Situation-Specific Evaluation Expert (SPEEX-battery) in identifying leadership potential, is important to:

1. ensure that employees with leadership potential are equitably identified, trained, developed and promoted into leadership positions;

2. provide an organisation with the opportunity to set specific targets as to the number of people or potential candidates earmarked for leadership positions in the future;

3. offer a logical structure for establishing and implementing plans to meet targets and eliminate problems;

4. monitor and evaluate the developmental progress made with people with leadership potential.

The present research is necessary as the measuring instrument (SPEEX) has been developed in South Africa and needs to be tested in the diverse South African context. It is essential that employees with leadership potential are equitably identified, trained, developed and promoted into leadership positions in order to initiate and maintain manpower growth and development, and to fulfil an entrepreneurial function in South Africa, especially as far as globalisation is concerned.

\section{Background and theoretical considerations}

According to Burns (1975), one of the most universal cravings of our time is a hunger for compelling and creative leadership. He adds that we fail to grasp the essence of leadership that is relevant to the modern age and hence we cannot even agree on the standards to measure, recruit, and reject it (Burns, 1975, p.2). Subsequently, Burns (1975) defined leadership as leaders inducing followers to strive for certain goals that represent the values and motivations of both leaders and followers.

The identification and prediction of leadership potential have always been a cause for concern in organisations. AlimoMetcalfe and Alban-Metcalfe (2001) noted that whereas the formal and empirical study of leadership began around the 1930s, the early 1980s witnessed a major paradigm shift in approaches to leadership, from Transactional to Transformational. They also stated that, while "earlier approaches, such as the situational and contingency models, focussed on identifying the behavioural styles which appeared to predict effective outcomes depending on situational contingencies, they offered little advice for dealing with the turmoil of the late 1970s and 1980s when constant change became the norm" (Alimo-Metcalfe \& Alban-Metcalfe, 2001, p.1).

It is necessary to understand what the competency profile of a leader is, in order to overcome limitations in the identification and prediction of leadership potential. This research article focuses on the identification of indices of the SPEEX-battery that validly identify leadership competencies.

As organisations move from being hierarchically structured entities to being digitally networked, the transactional styles of leadership conducive to hierarchies must evolve to suit the networked environment. Market globalisation, increasing diversity of workforces, and organisations' emphases on time, costs, quality and risk, are critical to their ability to compete with other organisations, locally and internationally. Researchers and organisations are increasingly interested in transformational/charismatic leadership theories as a possible solution to these challenges (Brown \& Lord, 1999).

\section{Transactional Leadership}

Over the years, research on leadership has provided several differentiating factors of exceptional leaders. Many leadership theories specify the qualities and behaviours that people associate with the term 'leader'. "Leadership can be understood in terms of knowledge, problem-solving skills, solution 
construction skills, and social judgement needed to solve organisational problems" (Mumford, Zaccaro, Conelly \& Marks, 2000, p.1). Whilst leadership has been defined in numerous different ways, according to Bass (1990) these definitions can be classified in accordance with the similarities between them. According to Bass and Avolio (1997), leadership behaviours can be viewed as a continuum of behaviours, ranging from the least potent, to the most potent.

Burns (1975) identified two basic types of leadership: the transactional and the transforming. Transactional leaders approach followers with the view to exchanging one thing for another. By contrast the transforming leader recognises and exploits an existing need or demand of a potential follower. "The exchange role of the leader has been referred to as transactional" (Ivancevich \& Matteson, 1993, p.466). Ivancevich and Matteson further hold that the transactional leader helps the follower identify what must be done to achieve the desired results, takes into consideration the person's self-concept and esteem needs and relies on contingent reward and management by exception. According to Bass and Avolio (1997), transactional leadership can be constructive or corrective. In its constructive form, transactional leadership is "supplemented by working with individuals and/or groups, setting up and defining agreements or contracts to achieve specific work objectives, discovering individuals' capabilities, and specifying the compensation and rewards that can be expected upon successful completion of the tasks" (p. 2). Bass and Avolio (1997) divided the corrective form of transactional leadership into passive (laissez-faire) and active. In the former, it focuses on waiting for mistakes to occur before taking action, whilst in the latter, transactional leaders closely monitor the occurrence of any mistakes.

According to Barbuto and Brown (2000), the full range leadership model, based on over 100 years of leadership research, identifies both transactional and transformational leadership. Transactional behaviours include laissez-faire (hands-off leadership), management by exception (putting out the fires) and contingent rewards (let's make a deal). Furthermore, laissezfaire leadership includes an absence of leadership, avoidance in taking a stand, no emphasis on results, refraining from intervention when issues arise and unawareness of employee performance (Barbuto \& Brown, 2000). In management by exception, the leader takes corrective actions, sets standards, but waits for problems to arise before doing anything, stresses what people are doing wrong, enforces rules and dislikes challenges to the status quo, and is only heard from when something is wrong. Transformational behaviours include individualised consideration (compassionate leadership), intellectual stimulation (thinking outside of the 'box'), inspirational motivation (exciting the masses/sharing the vision), and idealised influence (walking the walk) (Barbuto \& Brown, 2000).

Bass (1990, p.20) concluded, "the definition of leadership should depend on the purposes to be served by that definition". For the purpose of this study, leadership is referred to as an individual's ability to lead others by motivating them; managing interpersonal issues by being sensitive to diversity amongst others and integrating and being responsible for the achievement of performance targets and outputs (Bass, 1990).

According to Burns (1975) transformational leadership occurs when the leader and followers engage in such a way that they raise one another to higher levels of motivation and morality. "The transformational leader motivates followers to work for transcendental goals instead of short term self-interest and for achievement and self-actualisation instead of security" (Ivancevich \& Matteson, 1993, p.467). They add that transformational leaders are persuasive and motivational; and will "overhaul the entire philosophy, system, and culture of an organisation". "Transformational/charismatic leadership is usually contrasted with transactional leadership" (Den Hartog,
House, Hanges, Ruiz Quintanilla \& Dorfman, 1999, p.2). Bass and Avolio (1997, p.2) describe transformational leaders as those leaders who have the greatest influence on their subordinates and colleagues and as 'inspirational, intellectually stimulating, challenging, visionary, development oriented, and determined to maximise performance."

Transformational leadership, according to Moorhead and Griffon (1995, p.325), is "the set of abilities that allow the leader to recognise the need for change, to create a vision to guide that change, and to execute that change effectively". They state further that "only a leader with tremendous influence can hope to perform these functions". As Bass and Avolio (1997) started to collect and analyse their data on leadership, a new model of leadership began to take shape that incorporated a broader continuum of behaviours, from the least potent - laissez-faire leadership to the most potent - Idealised leadership.

\section{Components of transformational leadership}

Transformational leadership consists of four components: Charisma or Idealised influence (attributed or behavioural), Inspirational motivation, Intellectual stimulation, and Individualised consideration (Bass \& Avolio, 1997). The authenticity of transformational (or transactional) leadership is based on the moral behaviours, values and programmes of leaders (Bass \& Steidlmeier, 1999). Authentic transformational leadership provides a more reasonable and realistic concept of the self - a self that is connected to friends, family and community, whose welfare may be more important to one than one's own self (Bass \& Steidlmeier, 1999).

Bass and Avolio (1997) maintain that transformational leaders have associates who view them in an idealised way and, as such, these leaders wield much power and influence over their followers. "If the leadership is transformational, its charisma or idealised influence is envisioning, confident and sets high standards for emulation" (Bass \& Steidlmeier, 1999, p.5). Idealised influence is generally defined with respect to associates' reactions to the leader as well as to the leader's behaviour (Bass \& Avolio, 1997). Associates identify with and want to emulate those leaders, who are trusted and seen as having an attainable mission and vision. Attributionally, this type of leader reassures others that obstacles will be overcome. Behaviourally they emphasise the importance of having a collective sense of mission.

Leaders who have personal charisma often fail to develop associates to lead in their own right fearing a threat to their own leadership (Bass \& Avolio, 1997). As a result they are set up as idols. According to Bass and Steidlmeier (1999), followers should not merely be a means to satisfying ends for the leader but should be treated as ends in themselves. They label this variant of transformational leadership as inauthentic or pseudo (Bass \& Steidlmeir, 1999, p.5). These 'pseudo-transformational' leaders appear to be concerned about the development of associates but do not give them more autonomy and control or influence as part of their development (Bass \& Avolio, 1997, p.28).

According to Bass and Avolio (1997, p.28), "inspirational leaders articulate shared goals and mutual understanding of what is right and important, provide visions of what is important and how to attain them and enhance meaning and promote positive expectations about what needs to be done". They add that inspirational motivation may or may not overlap with idealised leadership, depending on the extent to which associates seek to identify with the leader. The leader provides symbols, metaphors, and simplified emotional appeals to increase awareness and understanding of mutually desired goals (Bass \& Avolio, 1997).

Bass and Steidlmeier (1999), claim that the inspirational motivation of transformational leadership provides followers with challenges and meaning for engaging in shared goals and 
understanding. This type of leader focuses on the best in people. Some researchers have linked this to an empowerment process, which for them is motivational and enabling, thus highlighting a new realisation and transformation of the person.

"Through Intellectual stimulation, transformational leaders help others to think about old problems in new ways" (Bass \& Avolio, 1997, p.29). Transformational leaders support associates who question their own values, beliefs and expectations as well as those who follow them in the organisation. They also support those who identify their shortcomings and suggest ways of developing themselves. Consequently, associates develop the capacity to solve future problems unforeseen by the leader and new and innovative solutions for the organisation are explored (Bass \& Avolio, 1997).

For Bass and Avolio (1997, p.29), individualised consideration "means understanding and sharing in others' concerns and developmental needs and treating each other uniquely" and "expanding and elevating those needs in an attempt to maximise and develop their full potential". Bass and Steidlmeier (1999, p.7) hold that "individualised consideration underscores the necessity of altruism if leadership is to be anything more than authoritarian control, where the leader treats every follower as an individual and provides coaching, and mentoring and growth opportunities". Bass and Avolio (1997) indicated further that assignments are delegated to associates to provide learning opportunities by treating them 'differently but equitably' on a one to one basis.

Transformational leadership and its augmentation effect for transactional leadership

Hooiberg and Choi (2000, p.6), in an interview with Bass quote Bass as saying that "passive and laissez-faire leaders have a negative impact on effectiveness". In this interview, Bass held that leaders may think they are empowering followers, but their followers may see them as trying to avoid work and not really caring about what they do. He adds, "while management by exception is sometimes necessary, some meta-analysts hold that it has an almost zero relationship with effectiveness" (Hooiberg $\&$ Choi, 2000, p.6). The transformational factors of individualised consideration, charismatic, and inspirational leadership as well as intellectual stimulation are likely to be more strongly correlated with effectiveness. However, transformational leadership does not replace transactional leadership. According to Bass and Avolio (1997, p.22), it "augments transactional leadership in achieving the goals of the leader, associate, group and organisation". Hooiberg and Choi (2000) also report Bass' stipulation that the augmentation effect is found in regression analysis where transformational leadership adds to transactional leadership in order to predict effectiveness and satisfaction. Although transformational leaders can be transactional when appropriate, transactional leadership is often a "prescription for lower levels of performance or non-significant change" (Bass and Avolio, 1997, p. 22).

Transformational leadership and culture specific and cross cultural generalisability

In accordance with the results of a global leadership and organisational behaviour effectiveness research programme, Den Hartog et al. (1999), maintain that although cross cultural research emphasises that different cultural groups are likely to have different conceptions of what leadership should entail, it is universally endorsed that attributes associated with transformational leadership contribute to outstanding leadership. They add that the cultural background of the perceiver strongly influences the way in which the social environment is interpreted.

According to Bass and Avolio (1997) the universality of the transactional/ transformational paradigm may be based on the fact that evidence supporting the model has been obtained in many different countries. This implies that "attributes which are seen as characteristic or prototypical for leaders may also strongly vary in different cultures e.g. in some cultures strong decisive actions may be necessary to be seen as a leader whereas in some cultures consultation and democracy may be a prerequisite" (Den Hartog et al., 1999, p.4).

In their article on transformational leadership, in the context of organisational change, Eisenbach, Watson and Pillai (1999), refer to the difficulty in measuring constructs such as leadership and change. They also mention the need to refine the instruments designed to measure transformational leadership. For the purposes of the present research, the scales of the Multifactor Leadership Questionnaire (MLQ) served as dependent variables, and various indices of the SPEEX-battery served as independent variables.

The MLQ has been used for assessments, reports and feedback on Leadership potential (Bass \& Avolio, 1997). An experimental form has also been used for research and further development of the MLQ that was eventually used for $360^{\circ}$ assessment and feedback. The psychometric data for the experimental form have been refined from research across "various business, industrial, nursing, military and professional organisations and agencies" (Bass \& Avolio, 1997, p.53). Bass and Avolio (1997) state that the mean factor scale values and norms are expected to vary across different organisations. Findings from validation and crossvalidational studies resulted in the selection of 45 items for the MLQ form 5X where 'four items were selected for each leadership factor that best represented the meaning of that construct" (Bass \& Avolio, 1997, p. 78).

Ackermann, Schepers, Lessing and Dannhauser (2000), performed a study to determine whether the factor structure of the MLQ, as a measure of transformational leadership, could be used in the South African context. In this study, the MLQ was administered to 406 subjects within a military context. The completed records were then subjected to factor analysis and item analysis. The factor analysis yielded three factors, namely, Transformational Leadership, Transactional Leadership and Avoidance of Leadership (Laissez-faire leadership).

The first factor consisted of items representative of transformational leadership, namely, idealised influence, individualised consideration, intellectual stimulation and inspirational motivation. The second factor consisted of items representative of the Laissez-faire leadership style. There were, however, five items that were more indicative of the management by exception (active) leadership style (Ackermann et al. 2000). Ackermann et al. (2000) argued that while the active leader closely monitors errors and problems, and the passive leader waits for mistakes and problems to occur, both concepts involve, 'avoidance' and therefore give meaning to the second factor namely, 'avoidance of leadership'. In the present study the items of the second factor have similar implications - they represent the laissez-faire leadership style. The third factor in Ackermann et al.'s study (2000) is transactional leadership. The items of this factor are representative of contingent reward and management by exception (active).

In a study of the predictive validity of the SPEEX-battery in an academic institution, Kriel (1999) found that the validity coefficients of certain of the indices of the SPEEX-battery exceeded internationally reported mean validities found in other and probably less situation specific assessment tools. Another study in a tertiary institution by Kriel (2000), to determine the "drop out" (success) rate of groups that were evaluated with the SPEEX assessment tool, concluded that this tool is highly successful in identifying students with the ability to be successful in tertiary studies.

\section{Objectives of the study}

The principal objective of the present study was to determine the association of certain indices of the Situation-specific Evaluation 
Expert (SPEEX) with the leadership dimensions of the Multifactor Leadership Questionnaire (MLQ). A corollary was to examine the factor structure and reliability of the SPEEXbattery and the MLQ. Thus the supplementary goals of the study were to:

- determine the factor structure of the indices of the SPEEXbattery known as SPEEX 1900, SPEEX 2200 and SPEEX 2400.

- calculate composite scores in respect of each of the factors obtained, and to estimate the reliabilities of each of the composites.

- determine the factor structure of the MLQ, and to estimate the reliabilities of each of the scales representing the factors obtained.

In the light of the principal objective of the study, the following hypothesis was formulated:

\section{Hypothesis 1}

There is a statistically significant canonical correlation between certain indices of the SPEEX-battery (IV's), and the leadership measures of the MLQ (DV's).

\section{RESEARCH DESIGN}

\section{Sample}

A sample of 108 bank managers was used in the study. It was randomly drawn from a population of 500 managers of one of the largest banks in South Africa. The mean age of the participants was 35 years with a standard deviation of 8 years. There were 56 men $(51,9 \%)$ and 52 women $(48,1 \%)$ in the sample. Their educational qualifications ranged from matriculation to post-graduate degrees, and their job levels from junior to middle management.

\section{Measuring instruments}

The SPEEX-battery

The Situation-specific Evaluation Expert (SPEEX), comprising 67 scales, provides a comprehensive assessment package suitable for the establishment and development of human potential in the workplace. For the purposes of the present study, 24 scales were selected from the total of 67 . The selected scales are categorised as Social Types (SPEEX 1900), Humanising (SPEEX 2400) and Leadership Style (SPEEX 2400). A brief description based on the Job Profiling Inventory (JPI Complete) from JP Expert/PIB SPEEX of the various scales follows.

\section{Social Types}

1 Demonstrative (I) 1

Demonstrative refers to the extent to which a person prefers to talk about things and to express his or her views about matters spontaneously in a way that may influence or inspire others or convince them.

$r_{x x}=0,562$

\section{Evaluating (I)}

Evaluating refers to the extent to which a person asks questions, investigates, looks into, searches, analyses, gives attention to, compares, attends to detail, plans and insists on quality.

$\mathrm{r}_{\mathrm{xx}}=0,48$

\section{Persevering (I)}

Persevering refers to the capacity of a person to be adamant, insistent, driven, a risk-taker, task-minded, punctual, assertive, arrogant, intolerant and challenging.

$r_{\mathrm{xx}}=0,49$

\section{Samaritarian (I)}

Samaritarian refers to the extent to which a person shows sympathy, companionship or support to others and/or willingness to assist others and to co-operate with them.

$\mathrm{r}_{\mathrm{xx}}=0,58$

\section{Emotional Quotient}

5. Diversity Facilitation $(\mathrm{N})^{3}$

Diversity Facilitation refers to the capacity of a person to relate positively to teams or other groups which reflect diversity in, for example, gender, culture, language, beliefs, attitude and behaviour.

$\mathrm{r}_{\mathrm{xx}}=0,63$

6. Emotional Sensitivity (N)

Emotional sensitivity refers to the capacity to understand and appreciate why people feel as they do when they are intolerant, concerned, downhearted, moody, angry, etc.

$\mathrm{r}_{\mathrm{xx}}=0,83$

\section{Empathy (N)}

Empathy refers to the capacity of a person to show concern, tolerance, sympathy and understanding for the needs, concerns, values, views, attitudes, behaviour, beliefs, etc. of other people. $\mathrm{r}_{\mathrm{xx}}=0,80$

8. Interpersonal Objectivity $(\mathrm{N})$

Interpersonal Objectivity is the capacity of a person to understand interpersonal matters for what they really mean. $\mathrm{r}_{\mathrm{xx}}=0,76$

9. Mental Stress $(\mathrm{N})$

Mental Stress refers to the capacity of a person to cope with emotional stress and pressure.

$\mathrm{r}_{\mathrm{xx}}=0,80$

10.People Development (N)

People Development refers to a person's appreciation for the developmental needs of workers in the workplace as well as their concern with the effective implementation of development procedures. It also relates to quality, time and attention, as very important and integral parts of daily activities in the workplace. $\mathrm{r}_{\mathrm{xx}}=0,86$

11. Physical Stress (N)

Physical Stress is the physical capacity of a person to cope with social and emotional stress, and is reflected by the absence of psychosomatic symptoms i.e., the physical manifestation of symptoms of stress.

$\mathrm{r}_{\mathrm{xx}}=0,82$

\section{Tact $(\mathrm{N})$}

Tact refers to the capacity of a person to be courteous, diplomatic, comforting, respectful, accommodating, etc. when attending to others' problems or difficulties.

$\mathrm{r}_{\mathrm{xx}}=0,83$

\section{Leadership Style}

A. Transformational Leadership Style

13.Big Picture Thinking (I)

Big Picture Thinking is the capacity of a person to realise the immediate and long-term implications and impacts of environmental trends, decisions, events, actions and problems on one's own performance and on the performance of followers. $\mathrm{r}_{\mathrm{xx}}=0,34$

14.Effort Focusing (I)

Effort Focusing is the capacity of a person to inspire team members to strive towards a shared goal or vision. $\mathrm{r}_{\mathrm{xx}}=0,50$

\section{Empowerment (I)}

Empowerment is the capacity of a person to remove obstacles that hinder the growth and achievement of followers and thus stimulate their willingness to show initiative and to work productively towards the shared goal or vision.

$\mathrm{r}_{\mathrm{xx}}=0,48$ 
16.Participative Management (I)

Participative Management is the capacity of a person to build common ownership of commitment to group goals, shared (team) vision, decision-making, problem-solving and management.

$\mathrm{r}_{\mathrm{xx}}=0,48$

\section{Transparency (I)}

Transparency refers to a person's openness and free sharing of information with others, as opposed to merely giving instructions. $r_{x x}=0,61$

\section{Visioning (I)}

Visioning is the capacity of a person to develop a clear vision of desirable futures and the ability to provide direction in terms of action towards certain future outcomes.

$r_{\mathrm{xx}}=0,48$

B. Transactional Leadership Style

19.Action Planning (I)

Action Planning refers to the capacity of a person to systematise, plan and prioritise an action with the required resources. $r_{x x}=0,63$

\section{Applied Strategic Planning (I)}

Applied Strategic Planning is the capacity to use 'big picture' thinking practically and proactively to form appropriate plans for realising strategic goals.

$\mathrm{r}_{\mathrm{xx}}=0,60$

21.Decisiveness (I)

Decisiveness is the capacity of a person to show readiness and ability to make decisions, render judgement, take action and apply corrective measures whenever the situation so demands. $\mathrm{r}_{\mathrm{xx}}=0,62$

22.External Motivation (I)

External Motivation is the capacity of a person to motivate team members by means of tangible rewards.

$r_{x x}=0,73$

23. Goal Setting (I)

Goal Setting is the capacity of a person to create objectives and plans that integrate the needs of diverse views and groups.

$r_{x x}=0,52$

\section{Organising (I)}

Organising is the capacity of a person to arrange the availability and allocation of required resources, to design and utilise control systems, and to delegate and co-ordinate the tasks and duties of individuals and groups, in a way that ensures the smooth flow of work throughout the workplace.

$\mathrm{r}_{\mathrm{xx}}=0,51$

From the foregoing, it is clear that the reliabilities of the normative scales range from 0,63 to 0,86 , and those of the ipsative scales from 0,34 to 0,73 . Ipsative measures can be used profitably to determine the relative strengths of intra-individual drives, but cannot be used to determine inter-individual differences. Clemans (1956, p.52) states it as follows: "Ipsative scores are relative scores. It is quite possible that a person obtaining a low ipsative score on a particular trait actually possesses more of the characteristics in question than a person obtaining a much higher ipsative score does. It is imperative that users of ipsative variables interpret them in the relative sense only". Paired comparisons, multiple rank orders, and forced choice formats normally lead to ipsative measurement. Sixteen of the scales of the SPEEX-battery are basically ipsative.

\section{The Multifactor Leadership Questionnaire (MLQ)}

The MLQ of Bass and Avolio (1997) focuses on a broad range of leadership behaviours and can be used to differentiate between effective and ineffective leaders. It is available in a validated short form of 45 items for organisational surveys and research as well as in a long form of 63 items for training and development purposes. Separate forms are available for self-assessment and 360 degree assessment purposes. It measures Transformational Leadership, Transactional Leadership, Non-transaction Leadership (Laissez-faire) and Outcomes of Leadership. The MLQ 5X (revised) selfassessment form was used in the present study. The MLQ (5X) (revised) (Copyright 1995 by Bernard M. Bass and Bruce J. Avolio), was used with permission of the local distributors of the instrument.

\section{Procedure}

The 24 scales of the SPEEX-battery, as well as the short form of the MLQ, were completed by the same sample of participants. One hundred and eight complete records were obtained.

\section{RESULTS}

\section{The SPEEX-battery}

To determine the factor structure of the 24 scales selected from the SPEEX-battery, the various measures were intercorrelated, and the eigenvalues of the unreduced intercorrelation matrix were computed. The eigenvalues are given in Table 1.

TABLE 1

EIGENVALUES OF UNREDUCED INTERCORRELATION MATRIX OF SPEEX-BATTERY

\begin{tabular}{lccc}
\hline Root & Eigenvalue & \% of Variance & Cumulative \% \\
\hline 1 & 4,997 & $\mathbf{2 0 , 8 2 1}$ & $\mathbf{2 0 , 8 2 1}$ \\
2 & 2,750 & $\mathbf{1 1 , 4 5 8}$ & $\mathbf{3 2 , 2 7 9}$ \\
3 & 2,055 & $\mathbf{8 , 5 6 4}$ & 40,843 \\
4 & $\mathbf{1 , 8 6 8}$ & $\mathbf{7 , 7 8 5}$ & $\mathbf{6 8 , 6 2 8}$ \\
5 & $\mathbf{1 , 5 9 5}$ & $\mathbf{6 , 1 0 3}$ & $\mathbf{5 5 , 2 7 2}$ \\
6 & $\mathbf{1 , 4 6 5}$ & $\mathbf{5 , 3 9 9}$ & $\mathbf{6 1 , 3 7 4}$ \\
7 & $\mathbf{1 , 2 9 6}$ & $\mathbf{4 , 2 7 4}$ & $\mathbf{6 6 , 7 7 3}$ \\
8 & $\mathbf{1 , 0 2 6}$ & 3,711 & $\mathbf{7 1 , 0 4 7}$ \\
9 & 0,891 & 3,281 & 74,758 \\
10 & 0,787 & 3,128 & 78,039 \\
11 & 0,751 & 2,798 & 81,167 \\
12 & 0,672 & 2,595 & 83,966 \\
13 & 0,623 & 1,944 & 86,561 \\
14 & 0,467 & 1,858 & 88,505 \\
15 & 0,446 & 1,601 & 90,363 \\
16 & 0,384 & 1,508 & 91,963 \\
17 & 0,362 & 1,399 & 93,471 \\
18 & 0,336 & 1,382 & 94,870 \\
19 & 0,332 & 1,264 & 96,252 \\
20 & 0,303 & 0,867 & 97,516 \\
21 & 0,208 & 0,795 & 98,383 \\
22 & 0,191 & 0,616 & 99,178 \\
23 & 0,148 & 0,206 & 99,794 \\
24 & 0,050 & & 100,000 \\
\hline Trace & 24,000 & & \\
\hline & & &
\end{tabular}

Table 1 shows that there are eight eigenvalues greater than unity. Accordingly, eight factors were extracted by means of a principal factor analysis (Kaiser, 1961). Two of the factors were poorly determined, therefore a six-factor-solution was obtained. The resulting factor matrix was rotated to simple structure by means of a Direct Oblimin rotation. This matrix is given in Table 2 .

Factor 1 is well determined, and can be identified as Interpersonal Relations. Factor 2 is also well determined and can be interpreted as Planning. Factor 3 is a doublet and can be tentatively identified as Perseverance. Factor 4 is well determined with four high loadings, and can be interpreted as Participative Management. Factor 5 is just determined with three loadings, and can be interpreted as Stress Tolerance. Factor 6 is also just determined, and can be interpreted as Visioning. The factor correlations are shown in Table 3. 
TABLE 2

ROTATED FACTOR MATRIX OF SPEEX BATTERY (DIRECT OBLIMIN ROTATION)

\begin{tabular}{|c|c|c|c|c|c|c|c|c|}
\hline Varia & $\begin{array}{c}\text { Factor } \\
1\end{array}$ & $\begin{array}{c}\text { Factor } \\
2\end{array}$ & $\begin{array}{c}\text { Factor } \\
3\end{array}$ & $\begin{array}{c}\text { Factor } \\
4\end{array}$ & $\begin{array}{c}\text { Factor } \\
5\end{array}$ & $\begin{array}{c}\text { Factor * * } \\
6\end{array}$ & $\mathbf{h}_{\mathbf{j}}^{2}$ & $r_{x x}$ \\
\hline act & 0,784 &, 030 & $-0,010$ & 0,059 & $-0,162$ & 0,100 & 0,682 & 0,83 \\
\hline Empathy & 0,756 &, 090 & $-0,104$ & 145 & 0,233 & 0,080 & 0,742 & 0,80 \\
\hline $\begin{array}{l}\text { Emotional } \\
\text { Sensitivity }\end{array}$ & 0,744 & $-0,030$ & 0,000 & 0,095 & $-0,133$ & 0,156 & 0,655 & 0,83 \\
\hline $\begin{array}{l}\text { Interpersonal } \\
\text { Objectivity }\end{array}$ & 0,732 & 0,080 & $-0,020$ & $-0,080$ & 0,215 & $-0,006$ & 0,569 & 0,76 \\
\hline $\begin{array}{l}\text { People } \\
\text { Development }\end{array}$ & 0,663 & 0,087 & 0,105 & $-0,090$ & 0,173 & $-0,183$ & 0,460 & 0,86 \\
\hline Evaluating & $-0,292$ & 0,200 & 0,017 & $-0,173$ & $-0,090$ & 0,030 & 0,221 * & 0,48 \\
\hline $\begin{array}{l}\text { Action } \\
\text { Planning }\end{array}$ & $-0,124$ & 0,723 & $-0,070$ & $-0,228$ & $-0,008$ & 0,349 & $0,729^{*}$ & 0,63 \\
\hline Goal Setting & 0,131 & 0,663 & $-0,040$ & 0,192 & $-0,040$ & 0,050 & $0,467^{*}$ & 0,52 \\
\hline Org & 0,020 & 0,641 & $-0,008$ & -0 , & -0 & & & 0,51 \\
\hline С一ा & $-0,040$ & 0,4 & 46 & -0 , & 0 , & 0,120 & $270^{*}$ & 0,62 \\
\hline $\begin{array}{l}\text { External } \\
\text { Motivation }\end{array}$ & $-0,030$ & 0,4 & 12 & 0,213 & $-0,006$ & $-0,244$ & $0,250^{*}$ & 0,73 \\
\hline $\begin{array}{l}\text { Demon- } \\
\text { strative }\end{array}$ & 0,308 & $-0,359$ & $-0,130$ & 0,121 & 0,263 & 0,080 & $0,453^{*}$ & 0,56 \\
\hline Persevering & 0,050 & 0,069 & 0,941 & 0,051 & $-0,134$ & $-0,085$ & $0,866^{*}$ & 0,49 \\
\hline San & $-0,0$ & 0 & -0 & & -0 & -0 , & & 0,58 \\
\hline $\begin{array}{l}\text { Participative } \\
\text { Management }\end{array}$ & 0,077 & 0,012 & $-0,003$ & 0,684 & $-0,004$ & 0,080 & $0,513^{*}$ & 0,48 \\
\hline Transparency & $-0,090$ & 0,189 & $-0,090$ & 0, & $-0,060$ & $-0,007$ & 0,459 * & 0,61 \\
\hline $\begin{array}{l}\text { Effort } \\
\text { Focusing }\end{array}$ & 0,182 & $-0,175$ & $-0,040$ & 0,586 & 0,043 & 0,217 & 0,601 * & 0,50 \\
\hline $\begin{array}{l}\text { Empower- } \\
\text { ment }\end{array}$ & 0,058 & $-0,145$ & 0,055 & 0,549 & 0,247 & $-0,082$ & $0,470^{*}$ & 0,48 \\
\hline Mental Stress & 0 , & 0,1 & -0 , & & & -0 , & 0,604 & 0,80 \\
\hline $\begin{array}{l}\text { Physical } \\
\text { Stress }\end{array}$ & $-0,050$ & $-0,003$ & 0,088 & 0,019 & 0,522 & 0,123 & 0,317 & 0,82 \\
\hline $\begin{array}{l}\text { Diversity } \\
\text { Facilitation }\end{array}$ & 0,244 & 0,244 & $-0,030$ & $-0,020$ & $-0,300$ & 0,060 & 0,226 & 0,63 \\
\hline $\begin{array}{l}\text { Big Picture } \\
\text { Thinking }\end{array}$ & $-0,090$ & $-0,090$ & 0,072 & 0,248 & , 104 & 0,688 & 0,601 * & 0,34 \\
\hline ing & 0,127 & -0 , & & & & & 9* & 0,48 \\
\hline $\begin{array}{l}\text { Applied } \\
\text { Strategic } \\
\text { Thinking }\end{array}$ & 0,048 & 0,111 & 0,003 & $-0,100$ & $-0,030$ & 0,485 & $0,254^{*}$ & 0,60 \\
\hline
\end{tabular}

Note.

** Factor 6 has been reflected

* These measures are basically ipsative

$\mathrm{r}_{\mathrm{xx}}$ Cronbach Alpha

TABLE 3

FACTOR CORRELATION MATRIX OF SPEEX BATERY

\begin{tabular}{lcccccc}
\hline Factor & Factor 1 & Factor 2 & Factor 3 & Factor 4 & Factor 5 & Factor 6 \\
\hline 1 & 1,000 & $-0,050$ & $-0,113$ & 0,266 & 0,063 & 0,114 \\
2 & $-0,050$ & 1,000 & 0,052 & $-0,162$ & $-0,175$ & $-0,063$ \\
3 & $-0,113$ & 0,052 & 1,000 & $-0,166$ & 0,091 & 0,080 \\
4 & 0,266 & $-0,162$ & $-0,166$ & 1,000 & 0,134 & 0,060 \\
5 & 0,063 & $-0,175$ & 0,091 & 0,134 & 1,000 & 0,070 \\
6 & 0,114 & $-0,063$ & 0,080 & 0,060 & 0,070 & 1,000 \\
\hline
\end{tabular}

Note. Factor 6 has been reflected

Table 3 shows that the factors are essentially uncorrelated or independent of one another. As many of the measures are ipsative in nature, and have rather low reliabilities it was decided to form composites by combining all the variables with substantial loadings on a factor.

The average reliability of the components used in forming the composites, and the average intercorrelations of the components are shown in Table 4.
TABLE 4

RELIABILITY OF THE VARIOUS COMPOSITE SCORES OF THE SPEEX-BATTERY

\begin{tabular}{|c|c|c|c|c|c|}
\hline \multirow{2}{*}{\multicolumn{2}{|c|}{ Composite }} & \multirow[t]{2}{*}{$\begin{array}{c}\text { Average } \\
\text { reliability of } \\
\text { components }\end{array}$} & \multirow[t]{2}{*}{$\begin{array}{c}\text { Average } \\
\text { inter- } \\
\text { correlation } \\
\text { of the } \\
\text { components } \\
\bar{\rho}_{g h}\end{array}$} & $\begin{array}{c}\text { Reliability } \\
\text { of the } \\
\text { composite }\end{array}$ & \multirow[b]{2}{*}{$\mathbf{k}$} \\
\hline & & & & $\bar{\rho}_{x^{\prime}}$ & \\
\hline 1 & Interpersonal Relations & 0,760 & 0,440 & 0,925 & 6 \\
\hline 2 & Planning & 0,595 & 0,286 & 0,833 & 6 \\
\hline 3 & Perseverance & 0,535 & 0,616 & 0,712 & 2 \\
\hline 4 & Participative Management & 0,518 & 0,424 & 0,788 & 4 \\
\hline 5 & Stress Tolerance & 0,750 & 0,247 & 0,833 & 3 \\
\hline 6 & Visioning & 0,604 & 0,348 & 0,767 & 3 \\
\hline
\end{tabular}

The following formula, developed by Schepers (1992, p. 62), was used to calculate the reliabilities of the composite scores:

$\rho_{x x^{\prime}}=\frac{\bar{\rho}_{g g^{\prime}}+(k-1) \bar{\rho}_{g h}}{1+(k-1) \bar{\rho}_{g h}}$,

$\rho_{x x^{\prime}}=$ reliability of composite

$\bar{\rho}_{g g^{\prime}}=$ average reliability of components

$\bar{\rho}_{g h}=$ average intercorrelation of components

$k=$ number of components

The obtained reliabilities of the various composite scores are also shown in Table 4 . From this table it can be seen that the reliabilities of the composite scores range from 0,712 to 0,925 . Reliabilities of this magnitude are acceptable for research purposes. The obtained composite scores were subsequently used as independent variables in a canonical correlation analysis.

The MLQ

Next, the 45 items of the MLQ were subjected to a principal factor analysis. As a first step, the items were intercorrelated and the eigenvalues of the unreduced intercorrelation matrix were computed. As fifteen of the eigenvalues were greater than unity fifteen factors were extracted and rotated to simple structure by means of a varimax rotation.

To overcome the effect of differential skewness of items, subscores in respect of each factor were computed by adding the items with high loadings on a factor together. The subscores were then intercorrelated and subjected to a principal factor analysis. The eigenvalues of the unreduced intercorrelation matrix are given in Table 5 .

Four factors were extracted, as four of the eigenvalues were greater than unity. Factor 1 represented 20 items and Factor 2, 11 items. Factors 3 and 4 were poorly determined, representing 6 and 7 items respectively. Accordingly, a three-factor-solution was tried. Factors 1 and 2 remained essentially the same. Factors 3 and 4 were combined into a single factor. No items were lost.

The obtained factor matrix was rotated to simple structure by means of a Direct Oblimin rotation, and is given in Table 6 .

Table 6 shows that the three factors are reasonably well determined, with substantial loadings on all three. However, from an inspection of the communalities it is apparent that 
several of the subscores share only a small proportion of their variance with the other subscores.

TABLE 5

EIGENVALUES OF UNREDUCED INTERCORRELATION MATRIX OF MLQ

\begin{tabular}{lccc}
\hline Root & Eigenvalue & \% of Variance & Cumulative \% \\
\hline 1 & 3,816 & 25,441 & 25,441 \\
2 & 1,665 & 11,098 & 36,539 \\
3 & 1,333 & 8,884 & 45,422 \\
4 & 1,247 & 8,311 & 53,733 \\
5 & 0,998 & 6,654 & 60,388 \\
6 & 0,914 & 6,093 & 66,480 \\
7 & 0,829 & 5,529 & 72,009 \\
8 & 0,788 & 5,251 & 77,260 \\
9 & 0,636 & 4,242 & 81,502 \\
10 & 0,568 & 3,788 & 85,289 \\
11 & 0,543 & 3,623 & 88,913 \\
12 & 0,501 & 3,340 & 92,252 \\
13 & 0,456 & 3,042 & 95,295 \\
14 & 0,389 & 2,595 & 97,890 \\
15 & 0,317 & 2,110 & 100,000 \\
\hline Trace & 15,000 & & \\
\hline
\end{tabular}

TABLE 6

ROTATED FACTOR MATRIX OF MLQ (DIRECT OBLIMIN ROTATION)

\begin{tabular}{|c|c|c|c|c|c|c|}
\hline \multirow{2}{*}{$\begin{array}{l}\text { Variables } \\
\text { Subtest } 1\end{array}$} & \multirow{2}{*}{$\begin{array}{l}\text { Item(s) } \\
44,31,26,30,42,16, \\
32,39,45 \& 15\end{array}$} & \multirow{2}{*}{$\frac{\mathrm{K}}{10}$} & \multicolumn{3}{|c|}{ Factor 1 Factor 2 Factor 3} & \multirow{2}{*}{$\frac{\mathbf{h}_{\mathbf{j}}^{2}}{0,683}$} \\
\hline & & & 0,538 & $-0,249$ & 0,343 & \\
\hline Subtest 2 & $41,21,35,43$ and 40 & 5 & 0,541 & $-0,183$ & 0,227 & 0,515 \\
\hline Subtest 3 & $33,7,12$, and 5 & 4 & $-0,216$ & 0,368 & 0,005 & 0,199 \\
\hline Subtest 4 & 20,3 and 24 & 3 & 0,091 & 0,752 & 0,058 & 0,542 \\
\hline Subtest 5 & 27 and 22 & 2 & $-0,030$ & 0,383 & 0,009 & 0,148 \\
\hline Subtest 6 & 37,38 and 10 & 3 & 0,630 & $-0,005$ & $-0,100$ & 0,360 \\
\hline Subtest 7 & 2 and 23 & 2 & $-0,010$ & 0,011 & 0,363 & 0,127 \\
\hline Subtest 8 & 34 and 8 & 2 & 0,207 & $-0,040$ & 0,510 & 0,397 \\
\hline Subtest 9 & $29,36,28$ and 19 & 4 & 0,096 & $-0,265$ & 0,356 & 0,287 \\
\hline Subtest 10 & 25 and 9 & 2 & 0,608 & 0,011 & 0,104 & 0,427 \\
\hline Subtest 11 & 18 and 11 & 2 & 0,187 & 0,232 & 0,289 & 0,167 \\
\hline Subtest 12 & 6 and 1 & 2 & 0,048 & $-0,050$ & 0,334 & 0,137 \\
\hline Subtest 13 & 13 and 4 & 2 & 0,199 & $-0,433$ & 0,128 & 0,312 \\
\hline Subtest 14 & 17 & 1 & 0,159 & 0,248 & $-0,250$ & 0,143 \\
\hline Subtest 15 & 14 & 1 & $-0,080$ & 0,072 & 0,737 & 0,486 \\
\hline mber & s per $\mathrm{f}$ & & 45 & 20 & 11 & 14 \\
\hline
\end{tabular}

To identify the obtained factors, the items associated with each one were grouped into the categories given by Bass and Avolio (1995). The resulting classification is given in Table 7 .

TABLE 7

ITEMS ASSOCIATED WITH THE THREE FACTORS OF THE MLQ

\begin{tabular}{llll}
\hline Items & Factor $\mathbf{1}$ & Factor 2 & Factor 3 \\
\hline $\begin{array}{l}\text { Transformational } \\
\text { Leadership }\end{array}$ & $\begin{array}{l}9,10,15,21, \\
25,26,30,31\end{array}$ & $\begin{array}{l}13 \text { (with a } \\
\text { negative } \\
\text { loading) }\end{array}$ & $\begin{array}{l}2,6,8,14,18,19, \\
23,29,34 \& 36\end{array}$ \\
$\begin{array}{l}\text { Transactional } \\
\text { Leadership }\end{array}$ & $\begin{array}{l}3,4,12,20,22, \\
24 \text { and } 25\end{array}$ & 1,11 and 17 \\
$\begin{array}{l}\text { Non-Transactional } 27 \\
\text { Leadership }\end{array}$ & None & 5,7 and 33 & 28 \\
$\begin{array}{l}\text { Leadership Outcome } \\
37,38,39,40,\end{array}$ & None & None \\
& $\begin{array}{l}41,42,43,44 \\
445\end{array}$ & 11 & 14 \\
$\begin{array}{l}\text { Total number } \\
\text { of items }\end{array}$ & 20 & & \\
\hline
\end{tabular}

Note. Categorisation of items according to Bass and Avolio (1995)
Table 7 shows that Factor 1 is strongly representative of items categorised as Transformational Leadership and Leadership Outcome. There were only two items categorised as Transactional Leadership. Factor 1 can therefore be identified as Transformational Leadership/Leadership Outcome.

Factor 2 represents items categorised as Transactional Leadership and Non-transactional Leadership (Laissez Faire). One item with a negative loading, was categorised as Transformational Leadership. The items listed as Transactional Leadership, all deal with failure to take action when required, and with keeping track of mistakes, irregularities, failures and complaints. Factor 2 can therefore be identified as Non-transactional Leadership.

Factor 3 is representative of items categorised as Transformational leadership, and also three items listed as Transactional Leadership. Factor 3 can therefore be identified as Transformational Leadership/Transactional Leadership.

The intercorrelations between the factors are given in Table 8 .

TABLE 8

FACTOR CORRELATION MATRIX OF MLQ

\begin{tabular}{lccc}
\hline Factor & Factor 1 & Factor 2 & Factor 3 \\
\hline 1 & 1,000 & $-0,116$ & $0,375^{* *}$ \\
2 & $-0,116$ & 1,000 & $-0,264^{*}$ \\
3 & $0,375^{* *}$ & $-0,264^{*}$ & 1,000 \\
\hline $\begin{array}{l}\text { Note: } \\
\text { ** Statistically significant at } 0,001 \text { level }\end{array}$ & & \\
* Statistically significant at 0,01 level & &
\end{tabular}

Table 8 shows that Factors 1 and 3 are positively correlated $(\mathrm{r}=0,375 ; \mathrm{p}<0,001)$, whereas Factors 2 and 3 are negatively correlated. $\quad(\mathrm{r}=-0,264 ; \mathrm{p}<0,01)$. Three scales were formed corresponding to the three factors obtained. To determine the reliabilities of these scales, they were subjected to item analysis using the NP 50 program.

The item statistics in respect of the first scale are given in Table 9.

TABLE 9

ITEM ANALYSIS OF SCALE 1 OF THE MLQ

\begin{tabular}{|c|c|c|c|c|c|}
\hline Item & $\mathrm{N}$ & $\begin{array}{c}\text { Mean of } \\
\text { item } \\
\bar{X}_{g}\end{array}$ & $\begin{array}{c}\text { Standard } \\
\text { deviation } \\
\text { of item } \\
s_{g}\end{array}$ & $\begin{array}{c}\text { Item - } \\
\text { total } \\
\text { correlation } \\
\mathrm{r}_{\mathrm{gx}}\end{array}$ & $\begin{array}{c}\text { Reliability } \\
\text { index of } \\
\text { item } \\
r_{g x} s_{g}\end{array}$ \\
\hline Q 9 & 108 & 4,176 & 0,771 & 0,539 & 0,415 \\
\hline Q10 & 108 & 3,713 & 0,762 & XXXX & $\mathrm{XXXX}$ \\
\hline Q15 & 108 & 3,852 & 0,759 & 0,487 & 0,369 \\
\hline Q16 & 108 & 4,000 & 0,785 & 0,521 & 0,409 \\
\hline Q21 & 108 & 4,306 & 0,676 & 0,482 & 0,326 \\
\hline Q25 & 108 & 3,815 & 0,763 & 0,549 & 0,419 \\
\hline Q26 & 108 & 3,769 & 0,953 & 0,683 & 0,651 \\
\hline Q30 & 108 & 4,139 & 0,716 & 0,560 & 0,401 \\
\hline Q31 & 108 & 4,074 & 0,693 & 0,700 & 0,485 \\
\hline Q32 & 108 & 4,102 & 0,683 & 0,559 & 0,382 \\
\hline Q35 & 108 & 4,620 & 0,524 & 0,506 & 0,265 \\
\hline Q37 & 108 & 4,111 & 0,601 & $\mathrm{XXXX}$ & $\mathrm{XXXX}$ \\
\hline Q38 & 108 & 4,093 & 0,604 & 0,600 & 0,363 \\
\hline Q39 & 108 & 3,861 & 0,791 & 0,668 & 0,528 \\
\hline Q40 & 108 & 4,028 & 0,859 & 0,671 & 0,576 \\
\hline Q41 & 108 & 4,472 & 0,587 & Xxxx & $\mathrm{XXXX}$ \\
\hline Q42 & 108 & 4,139 & 0,755 & 0,720 & 0,543 \\
\hline Q43 & 108 & 4,380 & 0,607 & 0,574 & 0,348 \\
\hline Q44 & 108 & 4,074 & 0,720 & 0,742 & 0,534 \\
\hline Q45 & 108 & 4,204 & 0,720 & 0,660 & 0,475 \\
\hline
\end{tabular}

Cronbach alpha $=0,889$

Mean of test $=69,630$

Standard deviation of test $=7,492$

Number of items $=17$ 
Table 9 shows that the obtained reliability in respect of Scale 1 is 0,889 . Three items were rejected, namely items 10,37 and 41 . The item-total correlations range from 0,482 to 0,742 . Thus the scale is internally highly consistent.

The item statistics in respect of the second scale are given in Table 10.

TABLE 10

ITEM ANALYSIS OF SCALE 2 OF THE MLQ

\begin{tabular}{|c|c|c|c|c|c|}
\hline Item & $\mathrm{N}$ & $\begin{array}{c}\begin{array}{c}\text { Mean of } \\
\text { item }\end{array} \\
\bar{X}_{g}\end{array}$ & $\begin{array}{c}\text { Standard } \\
\text { deviation } \\
\text { of item } \\
s_{g}\end{array}$ & $\begin{array}{c}\text { Item - } \\
\text { total } \\
\text { correlation } \\
\mathbf{r}_{\mathrm{gx}}\end{array}$ & $\begin{array}{c}\text { Reliability } \\
\text { index of } \\
\text { item } \\
\mathbf{r}_{\mathrm{gx}} \mathbf{s}_{\mathrm{g}}\end{array}$ \\
\hline Q3 & 108 & 2,361 & 0,971 & 0,501 & 0,486 \\
\hline Q4 & 108 & 2,500 & 1,046 & 0,569 & 0,595 \\
\hline Q5 & 108 & 1,593 & 0,854 & 0,434 & 0,371 \\
\hline Q7 & 108 & 1,380 & 0,575 & 0,402 & 0,231 \\
\hline Q12 & 108 & 1,667 & 0,710 & 0,532 & 0,378 \\
\hline Q13 & 108 & 4,287 & 0,684 & 0,414 & 0,283 \\
\hline Q20 & 108 & 1,491 & 0,779 & 0,478 & 0,373 \\
\hline Q22 & 108 & 3,139 & 1,000 & 0,580 & 0,580 \\
\hline Q24 & 108 & 2,861 & 1,106 & 0,612 & 0,678 \\
\hline Q27 & 108 & 2,759 & 1,040 & 0,362 & 0,376 \\
\hline Q33 & 108 & 1,722 & 0,863 & 0,453 & 0,391 \\
\hline
\end{tabular}

Cronbach alpha $=0,673$

Mean of test $=24,185$

Standard deviation of test $=4,742$

Number of items $=11$

Table 10 shows that the obtained reliability of Scale 2 is 0,673 and that the item-total correlations range from 0,362 to 0,612 . None of the items were rejected. The scale is internally highly consistent, but there are too few items.

The item statistics of the third scale are given in Table 11.

TABLE 11

ITEM ANALYSIS OF SCALE 3 OF THE MLQ

\begin{tabular}{|c|c|c|c|c|c|}
\hline Item & $\mathrm{N}$ & $\begin{array}{c}\text { Mean of } \\
\text { item } \\
\bar{X}_{\mathrm{g}}\end{array}$ & $\begin{array}{c}\text { Standard } \\
\text { deviation } \\
\text { of item } \\
s_{g}\end{array}$ & $\begin{array}{c}\text { Item - } \\
\text { total } \\
\text { correlation } \\
\mathbf{r}_{\mathrm{gx}}\end{array}$ & $\begin{array}{c}\text { Reliability } \\
\text { index of } \\
\text { item } \\
\mathbf{r}_{\mathrm{gx}} \mathrm{s}_{\mathrm{g}}\end{array}$ \\
\hline Q1 & 108 & 2,435 & 1,086 & 0,306 & 0,332 \\
\hline Q2 & 108 & 3,981 & 0,670 & 0,467 & 0,312 \\
\hline Q6 & 108 & 3,639 & 0,952 & 0,530 & 0,505 \\
\hline Q8 & 108 & 4,269 & 0,621 & 0,456 & 0,283 \\
\hline Q11 & 108 & 4,000 & 0,785 & 0,408 & 0,320 \\
\hline Q14 & 108 & 4,213 & 0,711 & 0,608 & 0,432 \\
\hline Q17 & 108 & 3,537 & 1,106 & 0,384 & 0,424 \\
\hline Q18 & 108 & 4,046 & 0,728 & 0,316 & 0,230 \\
\hline Q19 & 108 & 4,370 & 0,816 & 0,546 & 0,445 \\
\hline Q23 & 108 & 4,259 & 0,753 & 0,443 & 0,334 \\
\hline Q28 & 108 & 4,315 & 0,903 & 0,382 & 0,345 \\
\hline Q29 & 108 & 4,509 & 0,690 & 0,445 & 0,307 \\
\hline Q34 & 108 & 3,991 & 0,730 & 0,488 & 0,356 \\
\hline Q36 & 108 & 4,324 & 0,593 & 0,459 & 0,273 \\
\hline
\end{tabular}

Cronbach alpha $=0,664$

Mean of test $=55,889$

Standard deviation of test $=4,900$

Number of items $=1$

Table 11 shows that the obtained reliability of Scale 3 is 0,664 . None of the items were rejected. The item-total correlations range from 0,306 to 0,608 . Although the scale is internally highly consistent, there are too few items.

Returning now to the major objective of the study, the canonical correlations between the independent and dependent variables were calculated. To test the statistical significance of the obtained canonical correlations, Bartlett's chi-square test was used. The results are given in Table 12 .

TABLE 12

STATISTICAL SIGNIFICANCE OF CANONICAL CORRELATIONS: BARTLETT'S TEST

\begin{tabular}{lccccc}
\hline Eigenvalue & $\begin{array}{c}\text { Canonical } \\
\text { correlations removed }\end{array}$ & \multicolumn{3}{c}{$\begin{array}{c}\text { Significance of } \\
\text { remaining roots }\end{array}$} \\
\hline 0,443194 & 0,666 & 0 & 74,458 & 18 & $<0,000001$ \\
0,122075 & 0,349 & 1 & 14,733 & 10 & 0,142 \\
0,014147 & 0,119 & 2 & 1,453 & 4 & 0,835 \\
\hline
\end{tabular}

From Table 12 it is evident that only one of the canonical correlations is statistically significant $\left[\chi^{2}(18)=74,458\right.$; $\mathrm{p}<0,000001]$. The obtained canonical correlation is 0,666 .

The canonical correlation analysis is given in Table 13 .

TABLE 13

CANonical CORRelation analysis

\begin{tabular}{|c|c|c|c|c|c|}
\hline & \multirow[t]{2}{*}{$\begin{array}{l}\text { Canonical } \\
\text { Correlations }\end{array}$} & \multicolumn{3}{|c|}{$\begin{array}{l}\text { Correlations of Original } \\
\text { Measures with Canonical Variates }\end{array}$} & \\
\hline & & Variate 1 * & Variate 2 * & Variate 3 & \\
\hline & Independent Variables & & & & \\
\hline 1 & Interpersonal Relations & $\underline{0,844}$ & $-0,432$ & 0,213 & \\
\hline 2 & Planning & $-0,374$ & 0,038 & 0,595 & \\
\hline 3 & Perseverance & $\overline{0,269}$ & 0,206 & $-0,106$ & \\
\hline 4 & Participative Management & $\mathrm{t} \quad \underline{0,474}$ & 0,361 & 0,485 & \\
\hline 5 & Stress Tolerance & $\underline{0,386}$ & 0,707 & $-0,331$ & \\
\hline \multirow[t]{4}{*}{6} & Visioning & $\overline{0,399}$ & $-0,024$ & $-0,204$ & \\
\hline & $\begin{array}{l}\text { Average } \% \text { variance } \\
\text { accounted for }\end{array}$ & $24,28 \%$ & $14,34 \%$ & $13,29 \%$ & $\begin{array}{l}\text { Total: } \\
51,916 \%\end{array}$ \\
\hline & Average \% redundancy & $10,76 \%$ & $1,75 \%$ & $0,19 \%$ & $\begin{array}{l}\text { Total: } \\
12,7 \%\end{array}$ \\
\hline & Dependent Variables & & & & \\
\hline 7 & MLQ 1 & $\underline{0,927}$ & $-0,134$ & 0,351 & \\
\hline 8 & MLQ 2 & $-0,488$ & $-0,870$ & $-0,064$ & \\
\hline \multirow[t]{4}{*}{9} & MLQ 3 & $\underline{\underline{0,818}}$ & $-0,072$ & $-0,570$ & \\
\hline & $\begin{array}{l}\text { Average } \% \text { variance } \\
\text { accounted for }\end{array}$ & $58,90 \%$ & $26,02 \%$ & $15,08 \%$ & $\begin{array}{l}\text { Total: } \\
100 \%\end{array}$ \\
\hline & Average $\%$ redundancy & $26,10 \%$ & $3,18 \%$ & $0,21 \%$ & $\begin{array}{l}\text { Total: } \\
29,493 \%\end{array}$ \\
\hline & Canonical Correlations & 0,666 & 0,349 & 0,119 & \\
\hline
\end{tabular}

Table 13 shows that the following indices of the SPEEXbattery (IV's) have moderate to high loadings on the first variate: Interpersonal Relations, Participative Management, Stress Tolerance, and Visioning. Furthermore, the following scales of the MLQ (DV's) have moderate to high loadings on the same variate: Transformational Leadership/Leadership Outcome, Non-transactional Leadership, and Transformational Leadership/Transactional Leadership. As expected, the loading of Non-transactional Leadership (Laissez -faire) is negative. The highest loading on the independent side of the variate is on Interpersonal Relations $(0,844)$, and the highest loading on the dependent side is on Transformational Leadership/Leadership Outcome $(0,927)$. The loading on Transformational/ Transactional Leadership is comparably high $(0,818)$. The negative loading on Planning is probably meaningless for the small sample used $(\mathrm{N}=108)$ 
The independent variables accounted on average for only $24,28 \%$ of the variance of the $\mathrm{X}$-variate. The dependent variables, on the other hand, accounted on average for $58,90 \%$ of the variance of the Y-variate. The low percentage of variance accounted for by the independent variables is probably due to the ipsative nature of most of the scales used in the study.

As far as redundancy is concerned, the independent variables accounted for $10,76 \%$ of the variance of the Y-variate, and the dependent variables accounted on average for $26,10 \%$ of the variance of the X-variate. On the surface, this appears to be a contradiction. However, if canonical correlation analysis is compared with regression analysis, the results make good sense: The regression of $\mathrm{Y}$ on $\mathrm{X}$ is not the same as the regression of $\mathrm{X}$ on $\mathrm{Y}$.

The canonical correlation represents the correlation of the $\mathrm{X}$ composite with the Y-composite; given that the two composites have been formed by assigning weights to the X-components (independent variables) and the Y-components (dependent variables) so as to maximise the correlation between the two composites. The obtained canonical correlation is 0,666 , and is statistically highly significant.

\section{DISCUSSION}

The principal objective of this study was to determine how certain indices of the SPEEX-battery might relate to the leadership dimensions of the MLQ. A factor analysis of the SPEEX-battery yielded six factors, namely, Interpersonal Relations, Participative Management, Stress Tolerance, Planning, Perseverance and Visioning. A factor analysis of the MLQ yielded three factors, namely, Transformational Leadership/Leadership Outcome, Non-transactional Leadership and Transformational Leadership or Transactional Leadership.

From the results of the empirical research it can be concluded that certain indices of the SPEEX-battery, namely, Interpersonal Relations, Participative Management, Stress Tolerance and Visioning are associated with the Leadership dimensions of the MLQ, namely Transformational Leadership/Leadership Outcome, Non-transactional Leadership and Transformational Leadership/Transactional Leadership. A canonical correlation of $0,666 \quad(p<0,000001)$ was obtained between the indices of the SPEEX-battery (IV's) and the leadership dimensions of the MLQ (DV's). Thus, the hypothesis that there is a statistically significant canonical correlation between certain indices of the SPEEX-battery (IV's) and the leadership measures of the MLQ (DV's) is supported.

The canonical correlation also shows that Interpersonal Relations are strongly related to Transformational Leadership/Leadership Outcome and Transactional Leadership, and negatively related to Laissez-faire/Non-transactional Leadership. These findings are in accordance with the theory of transformational leadership. The Interpersonal Relations, Participative Management, Stress Tolerance and Visioning indices of the SPEEX-battery can therefore be used to predict transformational leadership. An important finding of the present study is that 10 items of transactional leadership, as described by Bass and Avolio (1997), are representative of the Laissez-faire (passive corrective) Leadership dimension. This style of leadership relates to hands-off leadership. It includes behaviours such as an absence of leadership, avoidance in taking a stand, no emphasis on results, refraining from intervention when issues arise and unawareness of employee performance. In contrast, the transactional leader, helps the follower identify what must be done to achieve the desired results, takes into consideration the person's self concept and esteem needs and relies on contingent reward and management by exception.

The major objective of a study by van Rensburg and Crous (2000), using the Jackson Personality Research Form (PRF-E) and the MLQ, was to identify the personality attributes of leaders high on transformational leadership. The distribution of scores on transformational leadership was divided into low and high scores. Two contrasting groups were formed i.e. those high on transformational leadership and those low on transformational leadership. The two contrasting groups were then contrasted on certain personality traits of the PRF-E and statistically significant differences in respect of the following variables were found: Change, Affiliation, Achievement and Impulsivity. Using a logistic regression equation with the above-mentioned variables, it was possible to correctly classify $86,5 \%$ of the subjects who obtained high scores on transformational leadership, and $63,2 \%$ of those with low scores.

The contribution that the present study makes to the field of leadership is that a certain combination of indices from the SPEEX-battery, including Interpersonal Relations, Participative Management, Stress Tolerance and Visioning, can be used by South African organisations to ensure that employees with transformational leadership potential are identified. Furthermore, relevant individual performance development plans, across the diverse South African spectrum, can also be based on the results of these assessments as part of a developmental gap analysis.

Appropriate identification and development of people with leadership potential will also contribute to compliance with the Employment Equity Act and the Skills Development Act by providing organisations with the opportunity to set and implement measures to achieve equity targets and organisational goals. Schaap (2001) expressed a similar view in a report on the psychometric properties of the SPEEX-battery, where the evidence suggests that the SPEEX scales allow compliance with the Employment Equity Act and the Skills Development Act. It is also important to note that as a part of fair labour practice, assessment tools such as the SPEEX-battery could be used in conjunction with other suitable evaluation methods, such as performance appraisal ratings, 360 degree ratings and panel interviews, amongst others, for selection.

Also, as more organisations in South Africa move towards flatter structures, continuous business improvement and digital networks (e-business), the need for transformational leadership becomes imperative. The survival of organisations is highly dependent on transformational leadership to facilitate the rapid changes. The premium placed on an organisation's ability to adapt, highlights the need for organisations to be able to predict transformational leadership potential in order to ensure organisational performance and service delivery. Transformational leaders must be easily identified and earmarked for development towards succession planning for business survival. Building trust, increasing the diversity of the workforce and developing the motivation to achieve the full capability of the workforce requires leadership to transcend transactional and laissez-faire styles and become more transformational. This can be done in the South African context, through the use of the SPEEX-battery.

The results of this study also suggest that future research on the SPEEX-battery be considered, using normative scales only. The low percentage of variance accounted for by the independent variables is probably due to the ipsative nature of most of the scales used in the study. Ipsative scales cannot be used to determine inter-individual differences; they can be used to measure intra-individual characteristics. The findings of this research suggest that a further investigation into leadership, using normative scales, is necessary.

In conclusion, the future of South African organisations is dependent on their ability to recognise transformational leaders and to place them in positions where they are able to drive the organisational vision efficiently and effectively. As a locally developed measuring instrument, the SPEEX-battery has been 
tested for situational predictive validity and reliability. The findings of this study suggest that this battery can be used by South African organisations that have the intention of competing with local organisations. This battery can also be used by organisations that wish to enter and compete in the global arena.

\section{REFERENCES}

Ackermann, C.P., Schepers, J.M., Lessing, B.C., Dannhauser, Z. (2000). Die faktorstruktuur van Bass se Veelfaktorleierskapsvraelys in die Suid-Afrikaanse konteks. Journal of Industrial Psychology, 26 (2), 58-67.

Alimo-Metcalfe, B. \& Alban-Metcalfe, R.J. (2001). The development of a new transformational leadership questionnaire. Journal of Occupational and Organisational Psychology, 74 (1), 1-27.

Barbuto, J.E. \& Brown, L.L. (2000). Full range leadership. Available from: http://www.ianr.unl.edu/pubs/consumered/ g1406.htm

Barling, J., Slater, F. \& Kelloway, K.E. (2000). Transformational leadership and emotional intelligence: an exploratory study. Leadership and Organisation Development Journal, 21 (3), 157 $-161$.

Bass, B.M. \& Avolio, B.J. (1995). Improving organisational effectiveness through transformational leadership. London: SAGE.

Bass, B.M. \& Avolio, B.J. (1997). Full range leadership development. Manual for the Multifactor Leadership Questionnaire. Palo Alto: Mind Garden, Inc.

Bass, B.M. (1990). Bass and Stogdill's handbook of leadership: Theory, research and managerial applications (3rd ed.). New York: The Free Press.

Bass, B.M. and Steidlmeier, P. (1999). Ethics, character, and authentic transformational leadership behaviour. Leadership Quarterly, 10 (2), 181 -218.

Brown, D.J. and Lord, R.G. (1999). The utility of experimental research in the study of transformational/charismatic leadership. Leadership Quarterly, 10 (4), 531-540.

CD Rom. Retrieved from JPEXPERT/PIBSPEEX.
Clemans, W.V. (1966). An analytical and empirical examination of some properties of ipsative measures. Psychometric Monograph Number 14.

Den Hartog, D.N., House, R.J., Hanges, P.J., Ruiz-Quintanilla, S.A. \& Dorfman, P.W. (1999). Culture specific and crossculturally generalizable implicit leadership theories: are attributes of charismatic/transformational leadership universally endorsed? [1]., Leadership Quarterly, 10 (2), 219 257.

Eisenbach, R., Watson, K. \& Pillai, R. (1999). Transformational leadership in the context of organisational change. Journal of Organisational Change Management, 12 (2), 80-87.

Hooiberg, R. \& Choi, J. (2000). From selling peanuts and beer in yankee stadium to creating a theory of transformational leadership: An interview with Bernie Bass. Leadership Quarterly, 11 (2), 291 - 307.

Huysamen, G.K. (1983). Psychological Measurement: An introduction with South African examples. Pretoria: Academica.

Ivancevich, J.M. \& Matteson, M.T. (1993). Organizational behaviour and management (3rd ed.) Boston: Irwin

Kaiser, H.F. (1961). A note on Guttman's lower bound for the number of common factors. British Journal of Statistical Psychology, 14 (1), 1.

Kriel, H. (1999). Horses for courses: situation specific selection revisited. Tecknikon Pretoria.

Kriel, H. (2000). Utilising the PIB in selection - a tertiary institution's perspective. Tecknikon Pretoria.

Moorhead, G. and Griffon, R.W. (1995). Organisational behaviour: Managing people and organisations. Boston: MA Houghton Mifflin Company.

Mumford, M.D., Zaccaro, S. J., Conelly, M.S. \& Marks, M.A. (2000). Leadership skills: conclusions and future directions. Leadership Quarterly, 11 (1), 155 - 172.

Schaap, P. (2001). The psychometric properties of the SPEEX (An updated version). University of Pretoria, Department of Human Resources Management, Pretoria.

Schepers, J.M. (1992). Toetskonstruksie: Teorie en praktyk. Johannesburg: RAU.

Van Rensburg, C. \& Crous, F. (2000). Die verband tussen sekere persoonlikheidseienskappe en transformasionele leierskap. Journal of Industrial Psychology, 26 (3), 39-46. 
In the pursuit of the ideals of excellence and diversity, the University of Pretoria wishes to invite applications for the following vacancy. Application forms are available on the Internet at

http://www.up.ac.za/personnel/employment/jobform.html

The University of Pretoria's commitment to quality makes us one of the top research universities in the country and gives us a competitive advantage in international science and technology development.

\section{DEPARTMENT OF HUMAN RESOURCES EAP@UP: ORGANISATION DEVELOPMENT EMPLOYEE ASSISTANCE PRACTITIONER}

Duties: Render an effective and efficient employee assistance programme within the University of Pretoria which includes: •Direct EAP services, including Aids counselling, to staff members in a manner that ensures timeousness and a strong code of ethics $\bullet$ Effective and confidential record-keeping and data management $\bullet$ Assessments, referrals and short-term problem solutions -Responsive intervention services in acute crises •Monitoring, follow-up and aftercare services to employees as well as the organisation as the employer and outside service providers -Training of employees, managers and supervisors •Psychometric testing and reports in case of management referrals.

Minimum requirements: - Registration with the Health Professions Council of SA (HPCSA) -Master's degree in Clinical Psychology •Five years' experience in Employee Assistance Programmes in the corporate environment as well as relevant qualifications in the Employee Assistance Programme •Appropriate language and communication skills $\bullet A$ valid Code EB driver's licence $\bullet$ Skilled in the use of the MS Office package •The successful candidate must be able to maintain good multicultural relations, exceptionally good human relations, function under pressure, provide a 24-hour service, maintain confidentiality and work as a multi-professional team member.

Recommended requirements: •At least eight years' relevant clinical experience in the field, of which five years must be in a corporate environment •At least one year's relevant experience within a tertiary institution.

For further particulars, contact Mrs R. Buys, (012) 420-4443.

CLOSING DATE: 30 June 2006.

Application forms must be submitted electronically or addressed to the Director: Human Resources. A complete CV must accompany the application.

The University of Pretoria is committed to equality, employment equity and diversity.

The University of Pretoria reserves the right not to make an appointment in the post as advertised.

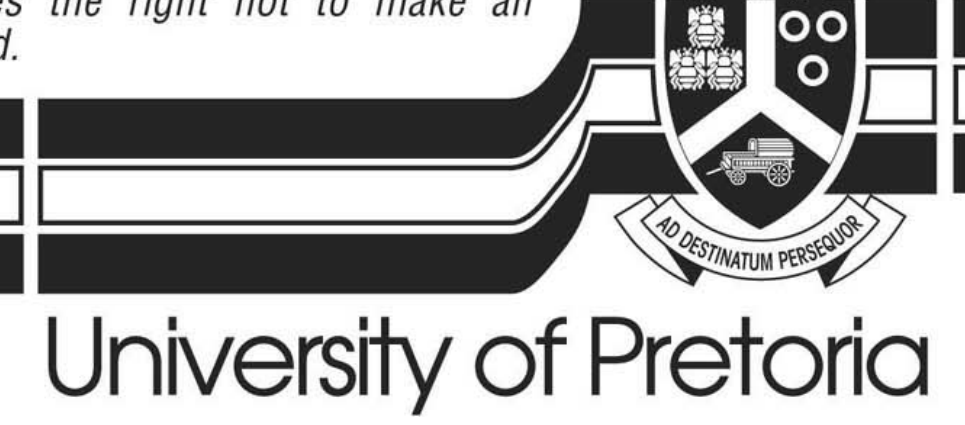

